Research Article

\title{
The Deformation Analysis of a Deep Frame Top-Down Excavation in Downtown Shanghai Based on the 3D FEM
}

\author{
Ting Bai $(\mathbb{D})$ and Dong Xie \\ GuangXi Polytechnic of Construction, Nanning, Guangxi 530007, China \\ Correspondence should be addressed to Ting Bai; baitng1984@163.com
}

Received 8 August 2021; Accepted 4 October 2021; Published 5 November 2021

Academic Editor: Xiaohu Zhang

Copyright (C) 2021 Ting Bai and Dong Xie. This is an open access article distributed under the Creative Commons Attribution License, which permits unrestricted use, distribution, and reproduction in any medium, provided the original work is properly cited.

\begin{abstract}
The deformation and environmental influence of the pit excavation in downtown is very important. A 3D FEM analysis is conducted to understand the deformation of a 13.9 to $15.2 \mathrm{~m}$ deep excavation with an in-plane dimension of about $189 \mathrm{~m}$ width and $251 \mathrm{~m}$ length constructed by the frame top-down method (FTDM) in the soft clay region in the Shanghai metropolitan area. The field monitoring results indicate that the magnitudes of wall deflections and ground settlements, along with the column's uplift difference, are relatively small, which are below the specified protection levels, and that the FTDM is feasible as one of the extralarge excavation construction methods. It is reasonable to predict wall deflection by 3D FEM simulation with qualitative comparison between the simulated column uplifts and the measured data, yet the prediction of the settlement distribution is of no satisfaction. This project studied in this paper not only serves as a special case study calibrated and verified by numerical tools but also provides insights into the design and construction of an extralarge deep excavation using the frame top-down method in soft soils and metropolitan environment.
\end{abstract}

\section{Introduction}

As the largest city and the commercial and financial center of China, Shanghai witnesses the construction of a growing number of high-rise buildings, subway transportation networks, and other underground structures, which provides broader platforms as well as higher challenges for excavation technology $[1,2]$. The innovative researchers and engineers are exploring and applying new technologies in the practical construction of the excavation. Three construction methods can be employed in the construction of an excavation, namely, the bottom-up method (BUM), the top-down method (TDM), and the anchor method [3]. The poor soil conditions of Shanghai prevent the application of the anchor method, which makes the bottom-up method and the traditional top-down method (TTDM, one type of the TDM) the most commonly employed approaches. The BUM is not environment-friendly due to its utilization of a large amount of temporary supports which may cause serious waste of resources, and its temporary support system is generally not stiff enough to minimize the deformation of the excavation. By using permanent flooring systems as support, it is stiff enough to minimize the deformation of the excavation, yet the TTDM requires hidden excavation [4-8]. Moreover, it will take a long period of time to construct the floor, such as form work, rebar, concreting, and curing, which leads to the extension of construction period as well as duration of unpropped wall exposure. Significant retaining wall deflections and ground movements may be induced due to the long construction period and unpropped wall exposure period caused by deep excavations in Shanghai in soft clay with high water content, low strength, and high rheology [9-12]. The frame top-down method (FTDM) is a special top-down method which applies beams as supports to make full use of advantages of both the BUM and the TDM. To be more specific, it not only is of higher support stiffness and environment-friendly but also avoids many other problems, such as long duration of unpropped wall exposure caused by hidden excavation.

Until now, there are two most promising ways for gaining an understanding of deep excavation performance, the finite 
element method and experience shared through published case histories. Since the publication of [13], many researchers and engineers contributed a huge amount of field data to the knowledge of performance of excavations and adjacent facilities [14-22]. More importantly, the empirical and semiempirical methods are mainly derived from field observations of case histories. Numerical analysis is another effective way to study complex problems in deep excavation [20, 23-28]. Due to the various types of foundation pit supporting structures and building foundations, the finite element method is the main method to evaluate the impact of the settlement of adjacent deep foundation excavation [29]. It is easier and cheaper to study deep excavation behavior with finite element analysis than using the instrument and monitoring of deep excavations. The current finite element numerical methods of foundation pits are mostly based on plane strain analysis, but foundation pits have obvious spatial effects. Three-dimensional finite element numerical analysis can effectively simulate the excavation of deep foundation pits with complex surrounding environments [30], which has great advantages.

This paper presents a case study of a deep frame topdown excavation in soft clay within the metropolitan area of Shanghai, China. The 3D FEM is employed to simulate the excavation process. This project and the relevant field data do not only facilitate thorough understanding of the general behavior of deep excavations constructed by the FTDM in soft clay within congested urban environments but also provide a good case history to calibrate and verify numerical tools. The findings and experience yielded from this study will be beneficial to designers, practitioners, and contractors for better understanding of the excavation project within the congested urban environment and reducing the risk of design and construction of the excavations.

\section{Project Information}

2.1. Project Location. As the largest city with a population of about 20 million in China, Shanghai is located at the estuary of Yangtze River on China's east coast. The city sits on the flat alluvial plain known as Yangtze River Delta, which features high groundwater tables and thick soft clay in the upper layers. The investigated project, excavation pit of Tangdong Headquarters site, is carried out in Pudong New Area, and some tower and podium buildings will be constructed there. The tower buildings include one 42-storied building, two 29-storied buildings, and two 18-storied buildings in frame-tube structure. The 3-level basement is in frame structure. Excavation depth of the tower block is $13.9-15.2 \mathrm{~m}$, while that of the podium block is $13.6 \mathrm{~m}$. The excavation area is shaped like a rectangle sized approximately $251 \mathrm{~m}$ by $189 \mathrm{~m}$ in plane and covers $46240 \mathrm{~m}^{2}$. Figure 1 presents the site plan of the project along with the instrumentation. On the north side of excavation, there is Jinkang Road which is $5.6 \mathrm{~m}$ away. On the south side are the Northern Jinjiang Hotel Phase 1 and Phase 2 buildings which are $22.6 \mathrm{~m}$ and $17.8 \mathrm{~m}$ away, respectively. On the western side, it is the Yanggao South Road with a $15 \mathrm{~m}$-wide urban green belt in between. On the northern side, it is the Huamu Road with a $10 \mathrm{~m}$-wide urban belt in between.
In order to avoid damage to adjacent structures and properties, Shanghai local code (SCMC, 2010) specifies three different protection grades (Table 1) for deep excavations; moreover, the criteria of deformation control of deep excavations are also established (refer to Table 2). According to this code, protection grade 2 is designated for construction of this deep excavation; i.e., the maximum excavation-induced wall deflection, $\delta \mathrm{hm}$, should be no more than $41 \mathrm{~mm}$ and the maximum ground settlements, $\delta \mathrm{vm}$, should be no more than $34 \mathrm{~mm}$. In addition, the allowable nonuniform settlement of the interior steel columns is specified as less than or equal to $20 \mathrm{~mm}$. These criteria are defined on the basis that the settlements should not cause apparent cracking to buildings nor severe damages to utilities.

2.2. Soil Properties. Prior to excavation, soil conditions at the site were explored by a series of field exploration programs (e.g., bore holes, standard penetration tests, and cone penetration tests). Soil profiles along with the basic soil properties are presented in Figure 2. The site was characterized by a thin layer of fill (layer I) in the upper $1.5 \mathrm{~m}$ below ground surface (BGS), followed by a layer of yellowish dark brown inorganic clay (layer II) at $3 \mathrm{~m} \mathrm{BGS}$. The next layer was very soft to soft silty clay (layer III) extending to $8 \mathrm{~m}$ BGS. Below layer III, there existed a layer of soft to firm silty clay (layer IV) extending to $17.5 \mathrm{~m}$ BGS. The next layer was grayish silty clay (layer V) extending to $24 \mathrm{~m}$ BGS, underlain by dark green stiff silty clay (layer VI) extending to $28 \mathrm{~m}$ BGS. Beneath layer VI, the field exploration encountered very dense silty fine sand interbedded with sandy silt (layer VII) till the termination at $75 \mathrm{~m}$ BGS. The observed depth of BGS of the long-term groundwater table ranged from $0.24 \mathrm{~m}$ to $1.30 \mathrm{~m}$. The unit weight, friction angle, and compression modulus of the upper silty clay are smaller than those of the lower silty fine sand, while the water content and void ratio of the silty clay are lower than those of the lower dense silty fine sand interbedded with sandy silt. The cohesion of stiff silty clay is greater than that of dense silty fine sand interbedded with sandy silt. The compressive modulus of soil is negatively correlated with the void ratio. The larger the void ratio, the smaller the compressive modulus.

2.3. Construction Sequence and Procedure. Construction activities are summarized in Table 3 . The site work began with construction of the retaining wall and the vertical support system as well as compaction grouting of the soils. The retaining wall is a contiguous pile wall which is usually adopted as a temporary wall in Shanghai. The contiguous piles were $28 \mathrm{~m}$ in length and $1050 \mathrm{~mm}$ in diameter, with a gap of $200 \mathrm{~mm}$ between two bored piles. Deep soil mixing columns, constructed at the back of contiguous pile walls, are used as waterproof curtains. The vertical support system is composed of steel lattice columns and bored piles which penetrate layer VII. The interior $\mathrm{H}$-section steel columns $(470 \mathrm{~mm} \times 470 \mathrm{~mm})$ were constructed in the deep-seated bored piles to sustain construction loads and serve as permanent structures for later use. Thereafter, excavation was initiated and strutting systems were propped as soils were 


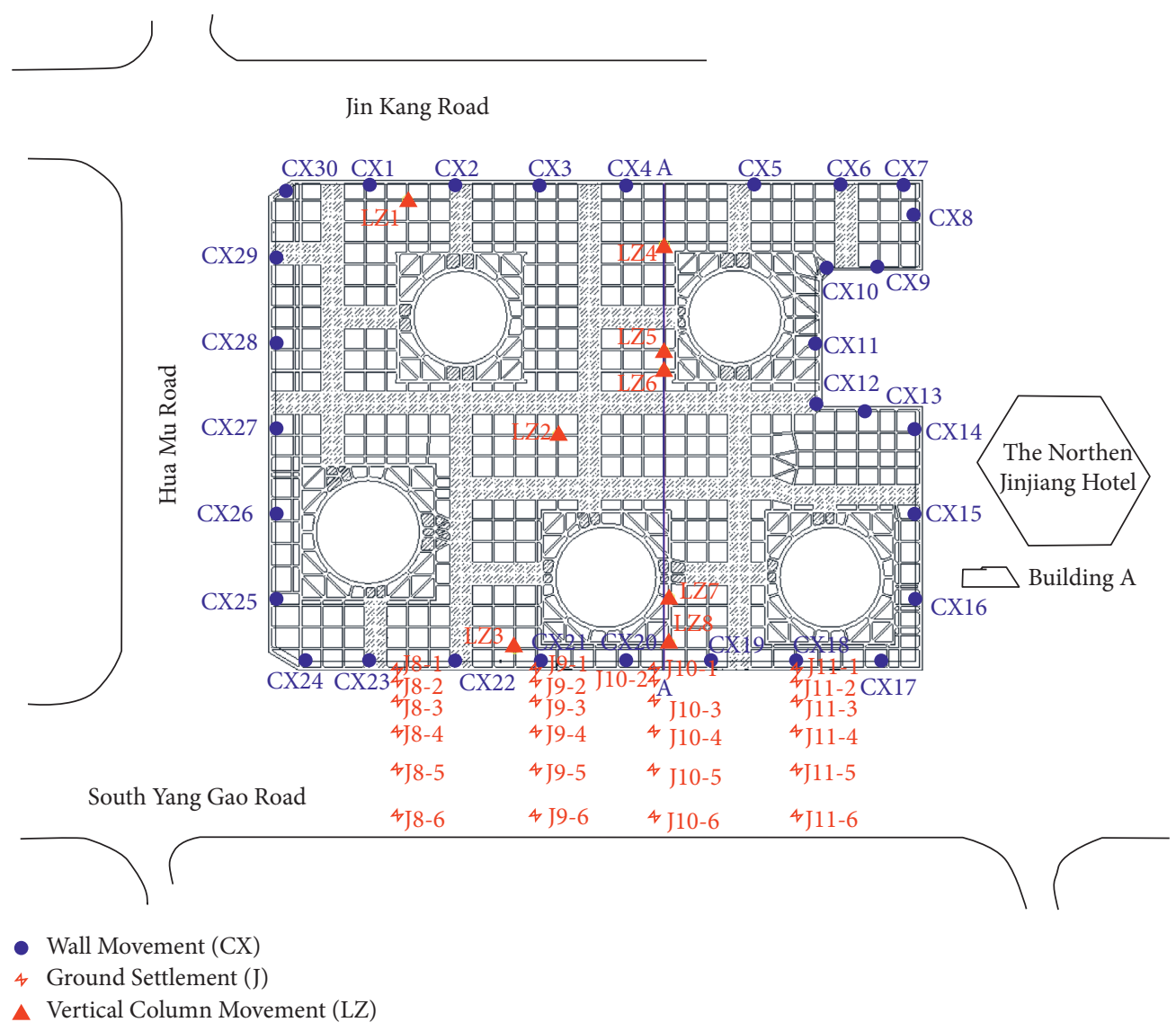

Figure 1: Plan of monitoring point arrangement.

TABle 1: Protection grade of deep excavations.

\begin{tabular}{|c|c|c|}
\hline Environmental conditions & $\begin{array}{l}\text { Distance of the structure or properties } \\
\text { from the excavation }(\mathrm{s})\end{array}$ & $\begin{array}{l}\text { Protection } \\
\text { grade }\end{array}$ \\
\hline \multirow{2}{*}{$\begin{array}{l}\text { Heritage buildings, factory buildings with precision instruments and machines, } \\
\text { important buildings with shallow foundations or short pile foundations, metro } \\
\text { lines, flood control walls, very important services such as water mains and gas } \\
\text { mains }\end{array}$} & $\begin{array}{c}S \leq \mathrm{He} \\
\mathrm{He}<S \leq 2 \mathrm{He}\end{array}$ & $\begin{array}{l}\text { I } \\
\text { II }\end{array}$ \\
\hline & $2 \mathrm{He}<S \leq 4 \mathrm{He}$ & III \\
\hline $\begin{array}{l}\text { Common buildings with shallow foundations or short pile foundations, } \\
\text { important services such as water supply pipes, gas pipes, and sewage pipes }\end{array}$ & $\begin{array}{c}S \leq \mathrm{He} \\
\mathrm{He}<S \leq 2 \mathrm{He}\end{array}$ & $\begin{array}{l}\text { II } \\
\text { III }\end{array}$ \\
\hline
\end{tabular}

Note. He is the excavation depth.

TABLE 2: Control criteria for protection environment.

\begin{tabular}{lcc}
\hline Protection grade & Maximum allowable displacement of the wall & Maximum allowable ground settlement \\
I & $0.18 \% \mathrm{He}$ & $0.14 \% \mathrm{He}$ \\
II & $0.3 \% \mathrm{He}$ & $0.25 \% \mathrm{He}$ \\
III & $0.7 \% \mathrm{He}$ & $0.55 \% \mathrm{He}$ \\
\hline
\end{tabular}

removed. The strutting systems were a combination of the beam and temporary reinforce concrete (RC) ring struts, which supported the contiguous pile wall. The underground structure was constructed in the base slabs, middle slabs, and roof slabs accompanied with removal of temporary RC ring struts. Young's modulus, $E$, of the concrete used at this site was $3.5 \times 10^{7} \mathrm{kPa}$.

\section{Field Monitoring}

To verify design assumptions and monitor the performance of the deep excavation for securing the safety of this project, a long-term comprehensive instrumentation program was conducted in situ. The deflections of the diaphragm walls were monitored by 30 inclinometer tubes (designated as 


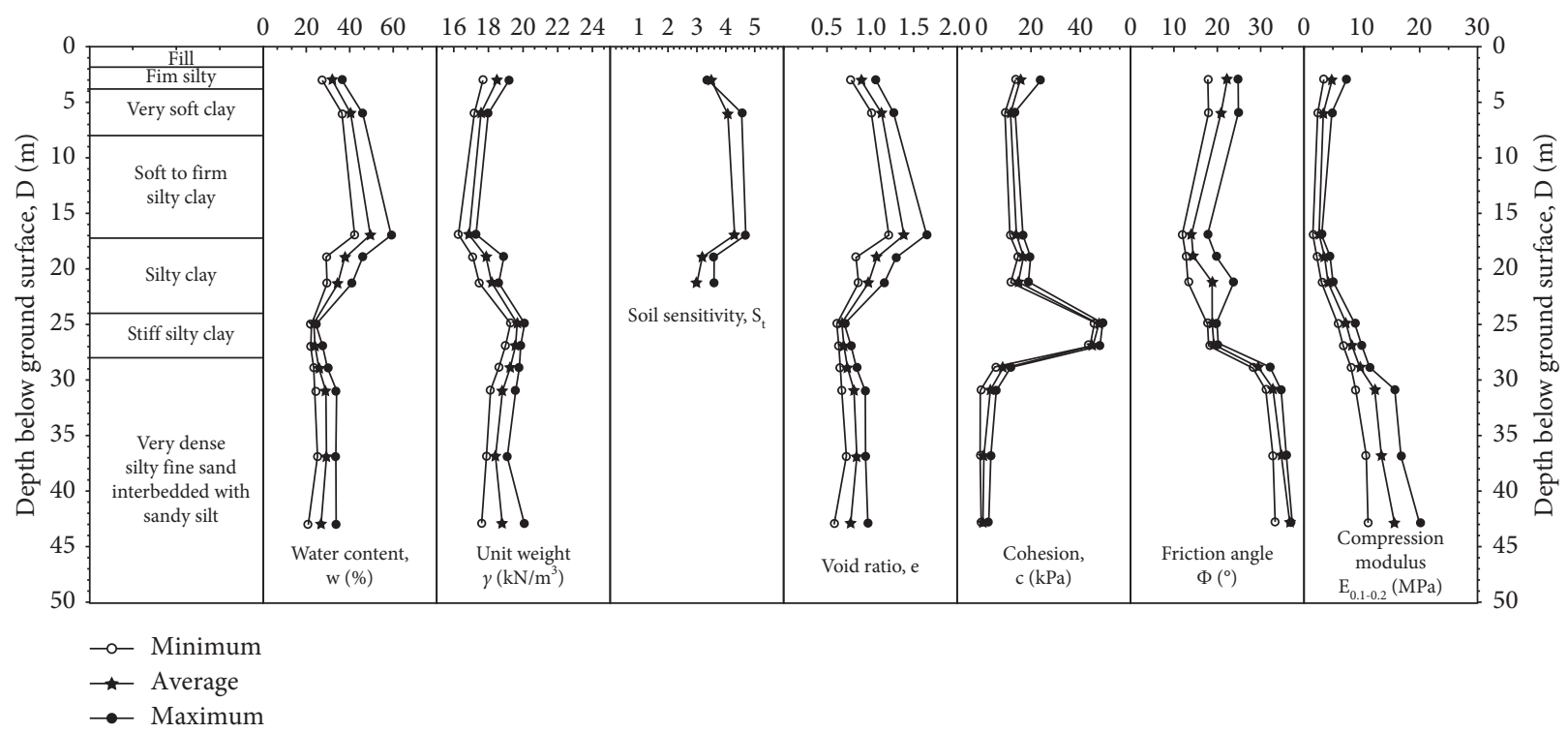

FIgURE 2: Soil profiles along with the material properties.

CX1 to CX30). In order to monitor the ground settlements behind the walls, 13 critical sections (designated as J1-1 JS16 to JS11-1 JS11-6) were selected for instrumentation. The vertical movements of the interior steel columns (designated as LZ1 tolz228) were monitored using an electronic total station instrument. More detailed information of the field monitoring can be found in [31]. It is helpful for the constructors to take reasonable measures to control the displacement of the wall to locate the places where the maximum wall deflection occurs.

Ground settlement has always been one of the major tasks faced by engineers. Based on massive measured data, many researchers studied the magnitudes and distribution patterns of ground settlement and established many empirical prediction methods. Peck [13] noted that deep excavation dewatering caused consolidation of soil and led to settlement of the ground next to an excavation. It will cause settlements over a much larger area than the area affected by the excavation itself. As for this excavation, outer waterproof curtains of \$850@600 triaxial cement/soil mixing piles which are $22.7 \mathrm{~m}$ long and pressure-reduction wells inside the pit which are $40 \mathrm{~m}$ deep are constructed, while shallowest surface of load-bearing water-containing strata at (7) layer is $27 \mathrm{~m}$ deep. The bottom of waterproof curtains fails to reach the load-bearing water-containing stratum which requires pressure reduction and dewatering, which leads to the failure of forming effective waterproof boundaries on load-bearing water-containing strata. This is why massive underground water pumped from the pit comes from horizontal runoffs below waterproof curtains, which will increase water level drop at load-bearing water-containing strata outside of the excavation pit and result in settlement of large areas outside of the excavation pit.

In these excavations by TDM, the magnitude of the interior column uplifts is an important criterion for quality assurance and quality control. As the deep-seated deflection of walls and base upheavals occur, soil outside of the pits moves inward to the pits. During construction, the interior columns will lift up inevitably. Nonuniform columns uplifts will produce sequential stress in the main structure or even induce failure of the main structure.

\section{Numerical Model and Material Parameters}

This excavation has a regular shape. This paper established a $1 / 4$ area of the symmetrical model at the southeast of the existing excavation pit in the analysis process to save calculation resources and facilitate modeling (Figure 3). Figure 4 shows a 3D numerical basic model. The established model is strictly in accordance with the physical and mechanical parameters of this excavation without consideration of the coupling action of underground water in numerical analysis. The hardening soil (HS) model is used to simulate the behavior of soil [32], and the parameters for the HS model listed in Table 4 can be considered as the representative of Shanghai soil. In addition, the retaining piles are equivalent to the diaphragm wall in the analysis. The excavation wall, frame beams, and columns were assumed to behave as a linear-elastic material, for which both Young's modulus and Poisson's ratio were assumed constant.

The following calculation steps were performed:

(i) Step 0: initial stress state

(ii) Step 1: activate wall (wished-in-place), set displacements to zero

(iii) Step 2: excavate to level $-1.15 \mathrm{~m}$

(iv) Step 3: activate strut (roof beam) at level $-0.58 \mathrm{~m}$

(v) Step 4: excavate to level $-5.85 \mathrm{~m}$

(vi) Step 5: activate strut (middle beam 1) at level $-5.05 \mathrm{~m}$

(vii) Step 6: excavate to level $-10.05 \mathrm{~m}$

(viii) Step 7: activate strut (middle beam (2)) at level $-9.05 \mathrm{~m}$ 
TABLE 3: State of foundation pit construction.

\begin{tabular}{|c|c|c|c|}
\hline Stage & Event & Date $(\mathrm{yy} / \mathrm{mm} / \mathrm{dd})$ & $\begin{array}{l}\text { Days } \\
\text { spent }\end{array}$ \\
\hline 0 & $\begin{array}{c}\text { Construction of retaining wall, steel lattice column, and bored pile as the vertical support system } \\
\text { and compaction grouting of the soils }\end{array}$ & $20081217-20090914$ & 272 \\
\hline 1 & $\begin{array}{l}\text { Excavation to } 1.15 \mathrm{~m} \mathrm{BGS} \text {; construction of the roof beam }(0.8 \mathrm{~m} \times 0.65 \mathrm{~m}) \text { and level } 1 \text { temporary } \\
\text { RC ring struts }(1.6 \mathrm{~m} \times 0.8 \mathrm{~m})\end{array}$ & $20090915-20091110$ & 57 \\
\hline 2 & $\begin{array}{l}\text { Excavation to } 5.85 \mathrm{~m} \text { BGS; construction of middle beam } 1(1.0 \mathrm{~m} \times 0.6 \mathrm{~m}) \text { and level } 2 \text { temporary } \\
\text { RC ring struts }(1.8 \mathrm{~m} \times 0.8 \mathrm{~m})\end{array}$ & $20091111-20100206$ & 88 \\
\hline 3 & $\begin{array}{c}\text { Excavation to } 10.05 \mathrm{~m} \text { BGS; construction of middle beam } 2(1.2 \mathrm{~m} \times 0.6 \mathrm{~m}) \text { and level } 3 \text { temporary } \\
\text { RC ring struts }(2.0 \mathrm{~m} \times 0.8 \mathrm{~m})\end{array}$ & $20100301-20100705$ & 127 \\
\hline 4 & Excavation to $13.6 \mathrm{~m}$ BGS (final level) & $20100706-20100928$ & 84 \\
\hline 5 & Construction of the base slab & $20100928-20101126$ & 58 \\
\hline 6 & Construction of the podium block & $20100903-20110227$ & 177 \\
\hline 7 & Construction of the tower block & $20101205-20110531$ & 178 \\
\hline
\end{tabular}

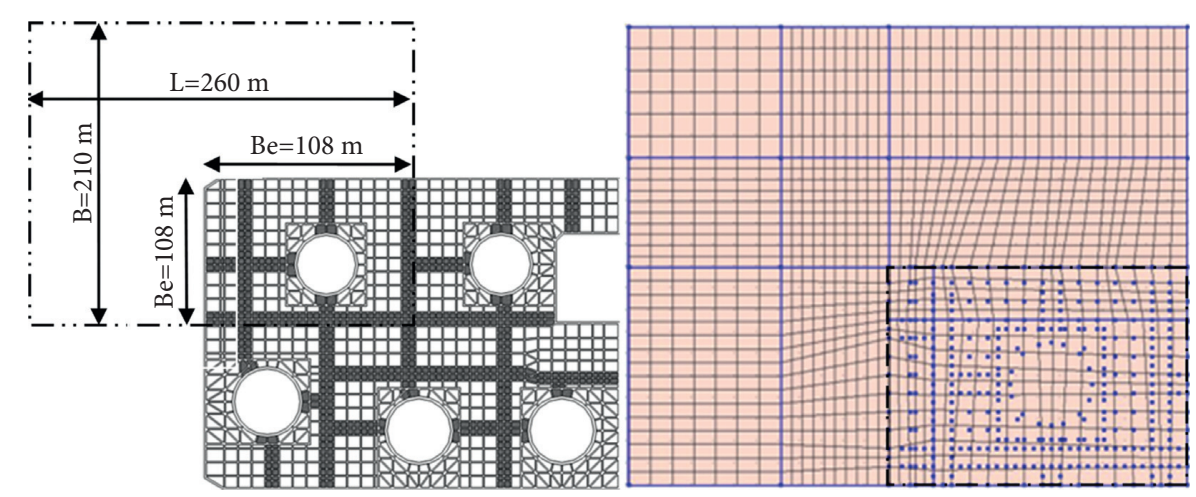

FIgURe 3: Plane size of the finite element model.

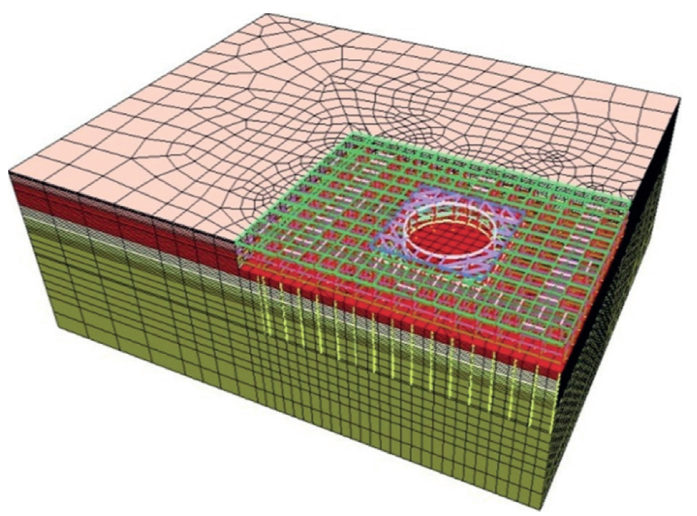

(a)

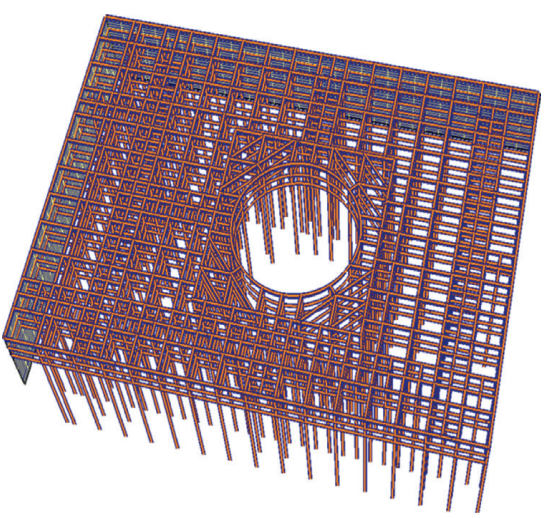

(b)

Figure 4: Numerical model. (a) Overall model. (b) Structural elements.

(ix) Step 8: excavate to level $-13.6 \mathrm{~m}$ (final level)

(x) Step 9: construction of base slab

\section{Results and Discussion}

5.1. Deflections of Retaining Walls. Figure 5 shows the comparison of the wall displacements from field measurements and those from FEM. As shown in the figure, the observations and predictions match well at each stage and share basically consistent distribution profiles. The wall deflection increases and the location of maximum wall deflection moves downwards as the excavation depth increases. The maximum wall deflection occurs near the excavation surface, where the data of wall deflection observed is smaller than the one predicted since the compaction grouting of the soils and area by area excavation were not considered in FEM. Wall deflection also occurs at the top of walls where the data of wall deflection observed is obviously larger than the one predicted because of the shrinkage and creepage of concrete structure beams. 
TABLE 4: Parameters for the hardening soil model.

\begin{tabular}{lcccccccccc}
\hline Layer & $c^{\prime}(\mathrm{kPa})$ & $\varphi^{\prime}\left({ }^{\circ}\right)$ & $\psi\left({ }^{\circ}\right)$ & $E_{\text {oed }}^{\text {ref }}(\mathrm{MPa})$ & $E_{50}^{\text {ref }}(\mathrm{MPa})$ & $E_{\text {ur }}^{\text {ref }}(\mathrm{MPa})$ & $M$ & $\nu_{u r}$ & $K_{0}^{n c}$ & $R_{f}$ \\
\hline II & 7 & 30.2 & 0 & 4.86 & 7.29 & 29.16 & 0.8 & 0.2 & 0.47 & 0.9 \\
III & 2 & 32.7 & 0 & 3.41 & 5.115 & 20.46 & 0.85 & 0.2 & 0.48 & 0.6 \\
IV & 7 & 27.6 & 0 & 2.13 & 3.195 & 12.78 & 0.85 & 0.2 & 0.57 & 0.6 \\
V & 12 & 29.5 & 0 & 4.25 & 6.375 & 25.5 & 0.8 & 0.2 & 0.47 & 0.9 \\
VI & 30 & 29.0 & 0 & 7.31 & 10.965 & 43.86 & 0.8 & 0.2 & 0.46 & 0.9 \\
VII & 4 & 33 & 3 & 15.05 & 22.575 & 90.3 & 0.5 & 0.2 & 0.35 & 0.9 \\
\hline
\end{tabular}

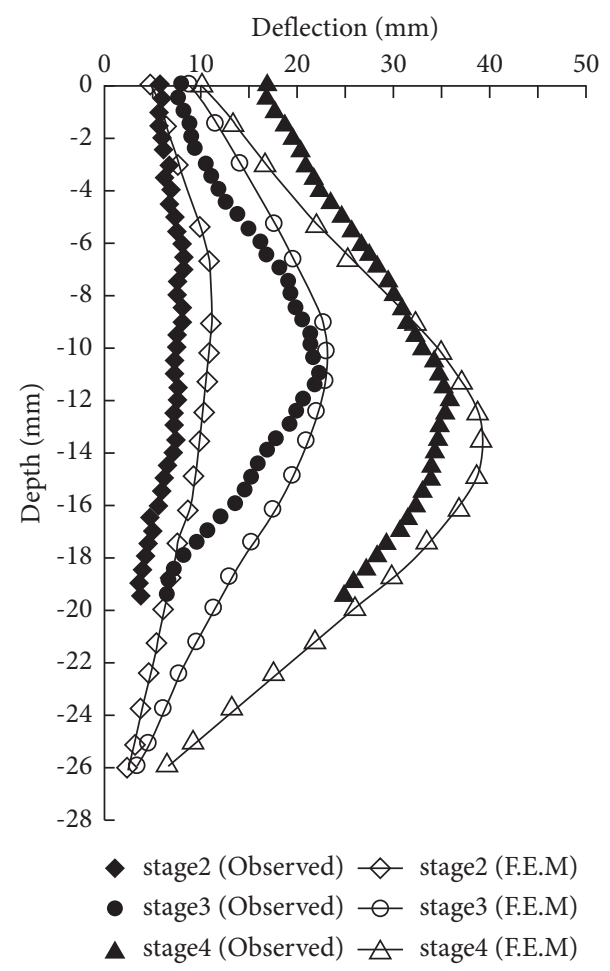

FIgURE 5: Comparison of the wall displacements from field measurements and from FEM at each stage.

5.2. Ground Settlements. The field observations of the ground settlement behind walls are located in the same section of the predictions in the FEM model, namely, sections J8-1 J8-6. According to the setting of the settlement observation point mentioned above, the area of the settlement observation section is approximately $900 \mathrm{~m}^{2}$. The observations and predictions of settlement behind walls increase when the excavation depth increases and are roughly consistent with displacement of the walls (Figure 6). In numerical analysis, ground settlement curve is shaped like a groove, with an obvious primary influence zone (PIZ) and secondary influence zone (SIZ), while the location of maximum ground settlement moves backwards when excavation goes deeper. This significantly differs from the observations. Moreover, the maximum ground settlement in numerical simulation is $14.9 \mathrm{~mm}$, about $0.11 \% \mathrm{He}$, and is close to the measured maximum ground settlement, both of which are less than $\delta \mathrm{vm}=0.25 \%$ He specified for the protection grade 2 (Table 2 ). Furthermore, statistic summary of 182 measured sections for subway excavation pits in Shanghai regions indicates that the maximum ground settlement is normally located at $0.5-0.7$ He horizontally from the retaining wall [33]. From numerical analysis of this project, it can be noticed that the maximum ground settlement is located at $0.75 \sim 1$ He behind the wall, while ground settlement behind the wall after 1 He decreases quickly and ground settlement behind the wall after $3 \mathrm{He}$ tends to be stable. This is consistent with $\mathrm{Xu}$ [34] in that extent of ground settlement of those excavations by TDM in Shanghai does not exceed $3 \mathrm{He}$ yet differs greatly from the observations. The differences attribute to the fact that dewatering is not considered in numerical simulation.

5.3. Uplifts of Interior Steel Columns. Column uplift tendency approaches the observations, both of which increase as the excavation depth increases. At stage 4, column uplifts tend to be stable. Differing from continuous increment of column uplifts in field measurement, column uplifts increase in trapezoid-shaped increment form in FEM (Figure 7). The reason is that practical excavation is performed area by area while the excavation process is in a continuous increment stage. In numerical analysis, excavation is performed layer by layer in a simplified way. After the completion of excavation, the predictions of column 


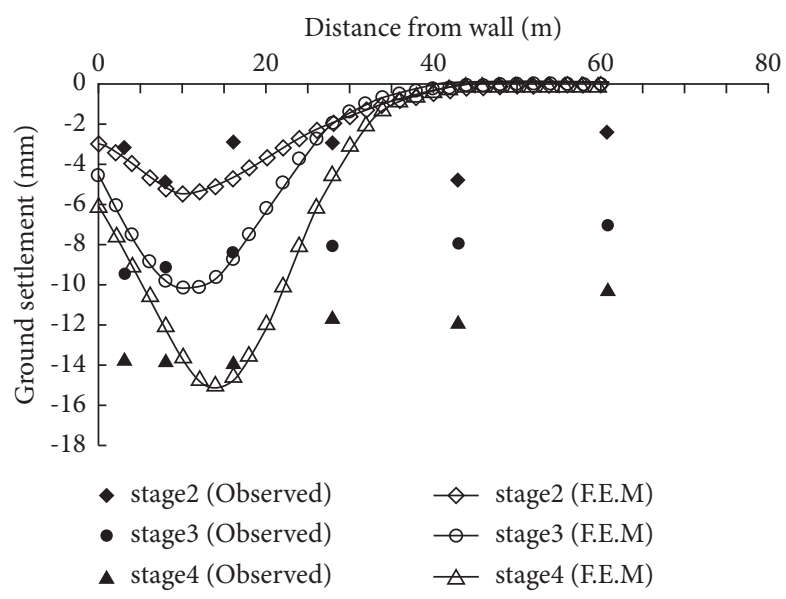

FIgURE 6: Comparison of the settlement profiles from field measurements and from FEM at each stage.

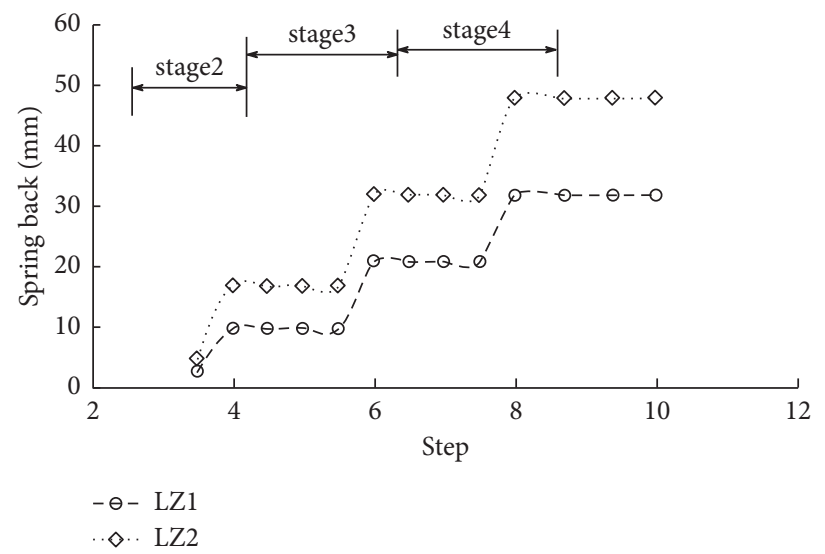

FiguRE 7: Vertical movements of interior steel columns observed from FEM at each stage.

maximum uplifts at two measure points are $46 \mathrm{~mm}$ and $31 \mathrm{~mm}$, respectively, while the observations of two measure points are $35 \mathrm{~mm}$ and $20 \mathrm{~mm}$, respectively. The predictions are slightly greater than the observations. The stress of the soil during the excavation of the foundation pit is released, and the soil in the pit rebounds. The load borne by the steel column includes the self-weight of the steel column and the friction resistance and the end resistance of the steel column. Because of the unloading due to the excavation, the steel column is uplifted by the soil around the column after each excavation stage. After the completion of excavation, the predictions of column maximum uplifts at two measure points are $46 \mathrm{~mm}$ and $31 \mathrm{~mm}$, respectively, while the observations of those are $35 \mathrm{~mm}$ and $28 \mathrm{~mm}$, respectively. The predictions are slightly greater than the observations. The reasons include the following: The practical working condition is excavating and concreting bottom slabs area by area, but it is simplified to large-area excavation layer by layer in numerical analysis. In practice, dewatering causes soil consolidation which results in soil stiffening; therefore, both the base upheavals and the column uplifts are restricted. It proves that technical measures mentioned above effectively limit the base upheavals and column uplifts.
Their uplifts differ when they are at different distances from wall at different stages. Column uplifts in the middle of the excavation pit are obviously greater, while the column uplifts close to the wall are usually smaller (Figure 8). At different stages, the steel columns at different positions in the foundation pit are subjected to different upward forces caused by the difference of soil surface height between the inside and outside of the foundation pit. With the increase in excavation depth, the upward force on the steel column in the foundation pit will be extremely large and the vertical displacement of the steel column will be extremely large, but because the steel column in different positions is subjected to different constraints, the rise of the steel column in different positions in the foundation pit will be different. For instance, the column uplift at LZ91 which is located in the middle of the excavation pit is $39 \mathrm{~mm}$ and the column uplift at LZ33 which is closer to the wall is $35 \mathrm{~mm}$. In numerical simulation, column uplifts follow similar tendency with field measurements, yet the magnitude of them is greater with the maximum and minimum values being $46 \mathrm{~mm}$ and $40 \mathrm{~mm}$, respectively, to be specific. In order to ensure the safety of structures, it is necessary to control the column uplifts difference. The Shanghai Construction and Management 


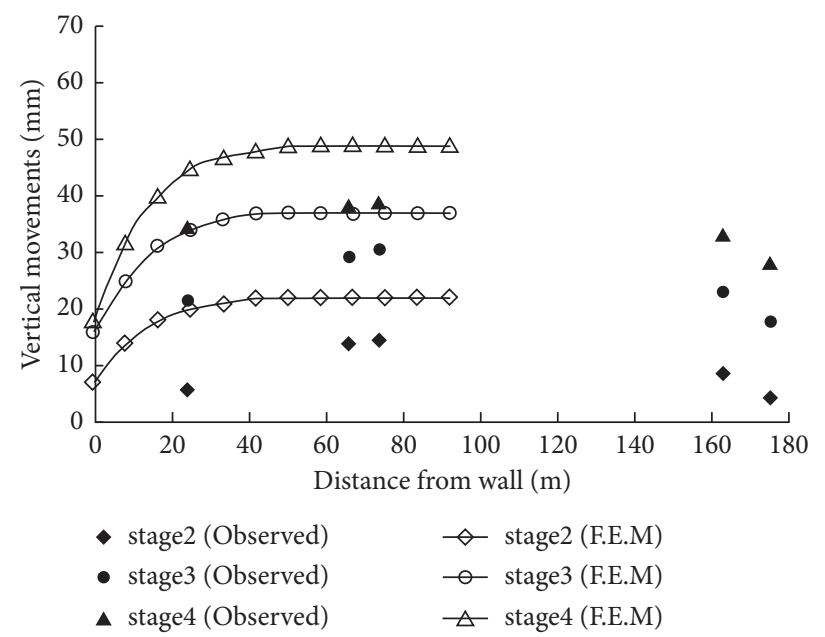

Figure 8: Comparison of the vertical movements of interior steel columns from field measurements and from FEM at section A-A.

Commission (2010) stipulates that column uplifts difference of two adjacent columns of the whole structure should be no more than $20 \mathrm{~mm}$ or L/400 (L refers to columns span). The observations and predictions of uplifts differences of adjacent columns are less than $5 \mathrm{~mm}$, which is in accordance with the design requirements.

Like the displacement of the wall, column uplifts also increase as the excavation depth increases at different stages. Column uplifts demonstrate significant $3 \mathrm{D}$ characters by the fact that column uplifts are greater in the middle of the excavation pit and smaller when close to the wall. Although the predictions of column uplift are greater than the observations, 3D numerical analysis can simulate column uplifts qualitatively in frame top-down excavation.

\section{Conclusions}

Through a long-term comprehensive instrumentation program and 3D numerical analysis, the performance of a deep excavation constructed by the FTDM in soft clay within downtown Shanghai was extensively explored. Based on the measured and predicted results, the following major conclusions can be drawn:

(1) As for those excavations using piles in row as the retaining wall, due to existence of ring beams and purlins, the displacement of the pile demonstrates space effects. However, the space effect of piles in row appears insignificantly compared with that of diaphragm walls. The time effects shall be taken into consideration in design and construction for the extralarge pit excavations in the sensitive soft soil, e.g., Shanghai soft soil. Compared with the observations, the predicted wall deflection from FEM without considering dewatering is relatively reasonable.

(2) 3D numerical analysis can, to some extent, simulate retaining wall displacement, ground settlement, and column uplifts resulting from the frame top-down excavation and offers a beneficial supplement to the understanding of deformation of complex deep excavation by FTDM. However, in the numerical analysis, issues such as selection of the soil constitutive model and simplification of numerical models (such as dewatering, frame beams' shrinkage, and seepage) should be taken into consideration. If this excavation is executed according to the finite element method, the displacement of the wall can be controlled properly and ground settlement will be underestimated, while column uplifts will be overestimated in practical construction. Hence, in project design, the designers or engineers should make a comprehensive judgment on the basis of numerical analysis and previous experiences.

\section{Data Availability}

All data can be made available from the authors upon request.

\section{Conflicts of Interest}

The authors declare that they have no conflicts of interest.

\section{Acknowledgments}

The authors thank the support from Professor Jingpei Li at Tongji University. This work was supported by the Key Research and Development Program of Jiangxi Province, China (Grant no. AB18281010).

\section{References}

[1] Y. Tan and D. Wang, "Characteristics of a large-scale deep foundation pit excavated by the central-island technique in Shanghai soft clay. I: bottom-up construction of the central cylindrical shaft," Journal of Geotechnical and Geoenvironmental Engineering, vol. 139, no. 11, pp. 1875-1893, 2013.

[2] P. He, Z. Xu, W. Wang, and Z. Li, "Observed performance of an ultra large deep excavation in Shanghai soft clay," in Proceedings of the Geoshanghai 2018 International Conference, pp. 161-170, Shanghai, China, May 2018. 
[3] N. S. Agrawal, V. Harne, J. Chouhan, and L. Gangwani, "Construction of plunge column by using top down construction method," Helix, vol. 10, no. 1, pp. 170-173, 2020.

[4] J. L. C. Mission and H.-J. Kim, "Design charts for elastic pile shortening in the equivalent top-down load-settlement curve from a bidirectional load test," Computers and Geotechnics, vol. 38, no. 2, pp. 167-177, 2011.

[5] H. Zheng, J. A. Dijksman, and R. P. Behringer, "Shear jamming in granular experiments without basal friction," $E P L$ (Europhysics Letters), vol. 107, no. 3, 2014.

[6] H. Zheng, D. Wang, X. Tong, L. Li, and R. P. Behringer, "Granular scale responses in the shear band region," Granular Matter, vol. 21, no. 4, 2019.

[7] M. M. Wang, D. Wang, J. E. S. Socolar, H. Zheng, and R. P. Behringer, "Jamming by shear in a dilating granular system," Granular Matter, vol. 21, no. 4, 2019.

[8] G. W. Clough and T. D. O'Rourke, "Closure to "construction induced movements of insitu walls" by G. W. Clough and thomas D. O'ourke (june 18-21, 1990, no. 25)," Journal of Geotechnical Engineering, vol. 118, no. 4, pp. 665-666, 1992.

[9] Y. Mei, D. B. Zhou, X. Y. Wang et al., "Deformation law of the diaphragm wall during deep foundation pit construction on lake and sea soft soil in the Yangtze river Delta," Advances in Civil Engineering, vol. 2021, Article ID 6682921, 11 pages, 2021.

[10] M.-G. Li, O. Demeijer, and J.-J. Chen, "Effectiveness of servo struts in controlling excavation-induced wall deflection and ground settlement," Acta Geotechnica, vol. 15, no. 9, pp. 2575-2590, 2020.

[11] Y. Q. Zhao, J. Bares, H. Zheng, J. Socolar, and B. P. Behringer, "Shear-jammed, fragile, and steady states in homogeneously strained granular materials," Physical Review Letters, vol. 123, no. 15, 2019.

[12] M. Long, "Database for retaining wall and ground movements due to deep excavations," Journal of Geotechnical and Geoenvironmental Engineering, vol. 127, no. 3, pp. 203-224, 2001.

[13] R. B. Peck, "Deep excavation and tunneling in soft ground," in Proceedings of the 7th International Conference on Soil Mechanics and Foundation Engineering, pp. 225-281, Mexico, 1969.

[14] A. I. Mana and G. W. Clough, "Prediction of movements for braced cuts in clay," Journal of the Geotechnical Engineering Division, vol. 107, no. 6, pp. 759-777, 1981.

[15] C.-Y. Ou, P.-G. Hsieh, and D.-C. Chiou, "Characteristics of ground surface settlement during excavation," Canadian Geotechnical Journal, vol. 30, no. 5, pp. 758-767, 1993.

[16] P.-G. Hsieh and C.-Y. Ou, "Shape of ground surface settlement profiles caused by excavation," Canadian Geotechnical Journal, vol. 35, no. 6, pp. 1004-1017, 1998.

[17] J. Roboski and R. J. Finno, "Distributions of ground movements parallel to deep excavations in clay," Canadian Geotechnical Journal, vol. 43, no. 1, pp. 43-58, 2006.

[18] G. T. Kung, C. H. Juang, E. C. Hsiao, and Y. M. Hashash, "Simplified model for wall deflection and ground-surface settlement caused by braced excavation in clays," Journal of Geotechnical and Geoenvironmental Engineering, vol. 133, no. 6, pp. 731-747, 2007.

[19] Y. M. A. Hashash, A. Osouli, and C. Marulanda, "Central artery/tunnel project excavation induced ground deformations," Journal of Geotechnical and Geoenvironmental Engineering, vol. 134, no. 9, pp. 1399-1406, 2008.

[20] F. Scharinger, H. F. Schweiger, and G. N. Pande, "On a multilaminate model for soil incorporating small strain stiffness," International Journal for Numerical and Analytical Methods in Geomechanics, vol. 33, no. 2, pp. 215-243, 2009.

[21] Y. Tan and B. Wei, "Observed behaviors of a long and deep excavation constructed by cut-and-cover technique in Shanghai soft clay," Journal of Geotechnical and Geoenvironmental Engineering, vol. 138, no. 1, pp. 69-88, 2012.

[22] Y. Tan and B. Wei, "Performance of an overexcavated metro station and facilities nearby," Journal of Performance of Constructed Facilities, vol. 26, no. 3, pp. 241-254, 2012.

[23] A. J. Whittle, Y. M. A. Hashash, and R. V. Whitman, "Analysis of deep excavation in boston," Journal of Geotechnical Engineering, vol. 119, no. 1, pp. 69-90, 1993.

[24] C.-Y. Ou, D.-C. Chiou, and T.-S. Wu, "Three-dimensional finite element analysis of deep excavations," Journal of Geotechnical Engineering, vol. 122, no. 5, pp. 337-345, 1996.

[25] Y. M. A. Hashash and A. J. Whittle, "Ground movement prediction for deep excavations in soft clay," Journal of Geotechnical Engineering, vol. 122, no. 6, pp. 474-486, 1996.

[26] Y. M. A. Hashash and A. J. Whittle, "Mechanisms of load transfer and arching for braced excavations in clay," Journal of Geotechnical and Geoenvironmental Engineering, vol. 128, no. 3, pp. 187-197, 2002.

[27] L. Zdravkovic, D. M. Potts, and H. D. St John, "Modelling of a 3D excavation in finite element analysis," Géotechnique, vol. 55, no. 7, pp. 497-513, 2005.

[28] A. Osouli, Y. M. A. Hashash, and H. Song, "Interplay between field measurements and soil behavior for capturing supported excavation response," Journal of Geotechnical and Geoenvironmental Engineering, vol. 136, no. 1, pp. 69-84, 2010.

[29] J. Chen, H. Mo, and S. Liu, "Evaluation on effect of building settlement due to adjacent deep excavation," in Proceedings of the 2nd International Conference on Civil Engineering, Architecture and Building Materials (CEABM 2012), Yantai, China, May, 2012.

[30] C.-Y. Ou, B.-Y. Shiau, and I.-W. Wang, "Three-dimensional deformation behavior of the Taipei National Enterprise Center (TNEC) excavation case history," Canadian Geotechnical Journal, vol. 37, no. 2, pp. 438-448, 2000.

[31] M. G. Li, J. H. Wang, J. J. Chen, A. M. Asce, and Z. Zhang, "Responses of a newly built metro line connected to deep excavations in soft clay," Journal of Performance of Constructed Facilities, vol. 31, no. 6, 2017.

[32] T. Schanz, P. A. Vermeer, and P. G. Bonnier, "The hardening soil model: formulation and verification," in Computational Geotechnics, pp. 281-296, Taylor and Francis, Boca Raton, NJ, USA, 1999.

[33] L. Tao, "Study on foundation pit safety assessment and deformation forecast on basis of numerical excavation," Ph.D. thesis, Tongji University, Shanghai, China, 2007.

[34] Z. H. Xu, "Deformation behavior of deep excavations supported by permanent structures in Shanghai soft deposit," Ph.D. thesis, Shanghai Jiaotong University, Shanghai, China, 2007. 